\title{
Benthic foraminifera in a deep-sea high-energy environment: the Moira Mounds (Porcupine Seabight, SW of Ireland)
}

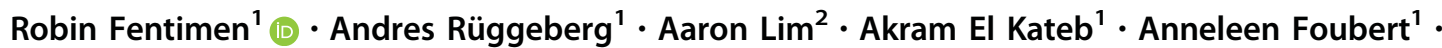 \\ Andrew J. Wheeler ${ }^{2,3} \cdot$ Silvia Spezzaferri ${ }^{1}$
}

\begin{abstract}
Cold-water coral ecosystems represent unique and exceptionally diverse environments in the deep-sea. They are well developed along the Irish margin, varying broadly in shape and size. The Moira Mounds, numerous small-sized mounds, are nestled in the Belgica Mound Province (Porcupine Seabight, North-East Atlantic). The investigation of living (Rose Bengal stained) and dead benthic foraminiferal assemblages from these mounds allowed to describe their distribution patterns and to evaluate their response to environmental variability. Quantitative data was statistically treated to define groups of species/genera associated to specific habitats. The Moira Mounds differ from their larger neighbours by the reduced spatial variability of benthic foraminiferal assemblages, living assemblages only distinguishing coral-rich and coral-barren areas. The ecological needs of corals are highlighted by the abundance of Alabaminella weddellensis and Nonionella iridea, phytodetritus-feeding species in coral supporting sediments. Living foraminifera in sediments from the Moira Mounds concentrate in the upper first centimetre. Infaunal species may be affected by bioturbation and/or reworking by the strong currents in the area. Dead foraminiferal assemblages from the Moira Mounds resemble those described for the sandwave facies in adjacent giant mounds, suggesting similar processes in facies deposition.
\end{abstract}

Keywords Benthic foraminifera $\cdot$ Cold-water corals $\cdot$ Carbonate mounds $\cdot$ Bio-sedimentary facies

\section{Introduction}

In recent years cold-water coral (CWC) ecosystems have been studied in the Mediterranean Sea (Fink et al. 2013; Lo Iacono et al. 2014), on the Norwegian shelf (Freiwald et al. 2002; Rüggeberg et al. 2011; Stalder et al. 2014), along the

Editorial handling: Daniel Marty.

Electronic supplementary materia

Robin Fentimen

robin.fentimen@unifr.ch

1 Department of Geosciences, University of Fribourg, Fribourg, Switzerland

2 School of Biological, Earth and Environmental Sciences, University College Cork, Distillery Fields, North Mall, Cork, Ireland

3 Irish Centre for Research in Applied Geosciences, University College Cork, Cork, Ireland
Moroccan margin (Foubert et al. 2008; Wienberg et al. 2009) and off Mauritania (Eisele et al. 2014). However, the most intensively studied area remains the Irish margin (Hovland et al. 1994; De Mol et al. 2002; Beyer et al. 2003; Mohn et al. 2014; Hebbeln et al. 2016, and references therein). Offshore Ireland, CWCs composed of Lophelia pertusa and Madrepora oculata and hosting complex ecosystems characterize the seafloor (e.g., Freiwald et al. 2004; Vertino et al. 2015).

The Belgica Mound Province is located on the eastern margin of the Porcupine Seabight (PS), a shallow to deepwater north-south trending embayment in the northeast Atlantic continental margin (De Mol et al. 2002; Wheeler et al. 2007; Huvenne et al. 2009a). It is $45 \mathrm{~km}$ long and $10 \mathrm{~km}$ wide (Fig. 1), and hosts active or buried CWC mounds from 550 to $1030 \mathrm{~m}$ water depth. Mound size varies from giant representatives, e.g., Challenger or Galway Mound, reaching approximately $150 \mathrm{~m}$ in height (Ferdelman et al. 2005; Dorschel et al. 2007b; Foubert and Henriet 2009) to small-sized structures, e.g., the 256 Moira Mounds (MM) offshore western Ireland (Fig. 1) (Foubert 


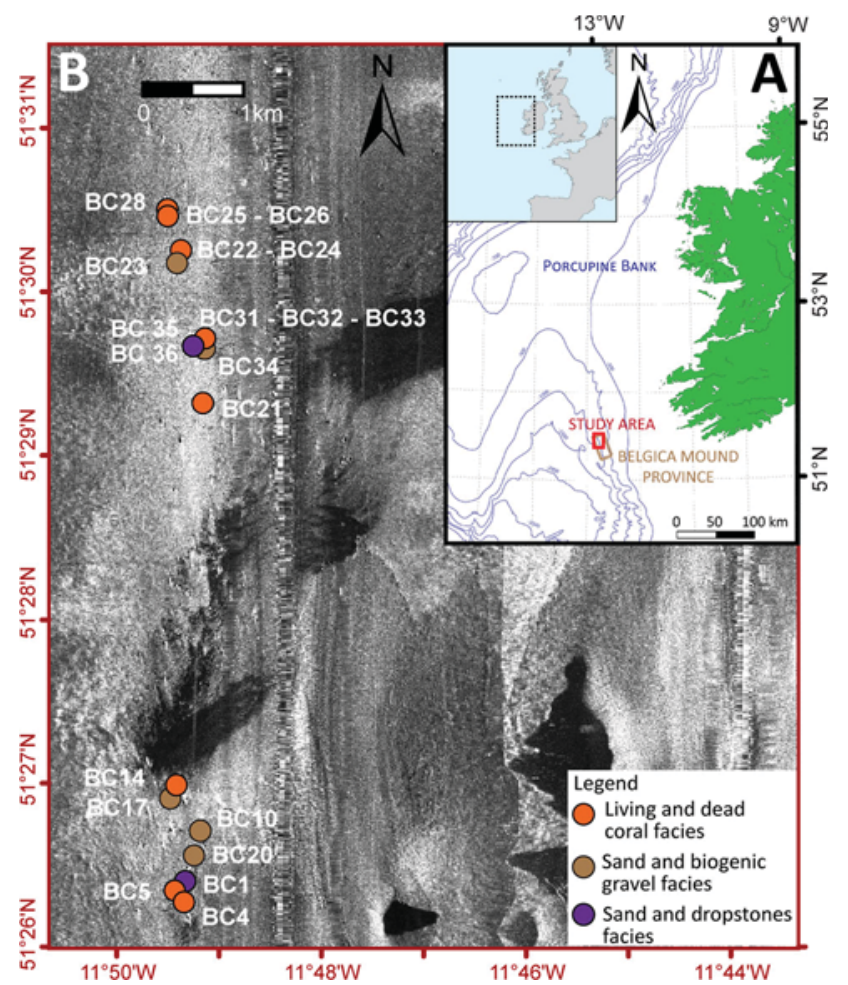

Fig. 1 (A) Location of the Belgica Mound Province (brown box) and the study area (red box). (B) Detailed $30 \mathrm{kHz}$ side-scan sonar (TOBI) mosaic of the study area showing the location of the 20 box cores (BC) together with their facies classification (mod. from Wheeler and Science Party 2011)

et al. 2011; Wheeler et al. 2011; Lim et al. 2017, 2018). Based on video surveys, Wheeler et al. (2011) described a downslope area (Fig. 1) characterized by 143 small mounds between 900 and $1150 \mathrm{~m}$ water depth. These mounds have ovoid shapes, diameters of 20-50 m, heights of up to $11 \mathrm{~m}$, slope gradients ranging between $15^{\circ}$ and $20^{\circ}$, and their long-axis are oriented parallel to the dominant north-south flowing current (Wheeler et al. 2005, 2011; Foubert et al. 2011). Foubert et al. (2011) suggested that the midslope MM may represent the initial start-up phase of mound formation or an example of mound formation under stressed conditions.

The northward circulating Eastern North Atlantic Water (ENAW) and the Mediterranean Outflow Water (MOW) influence the PS. The ENAW, extending down to $800 \mathrm{~m}$, overlays the MOW, which extends from around 800-1100 m depth (Rice et al. 1991; White 2007). The MOW is highly saline and its upper limit corresponds to the permanent thermocline (White 2007). It flows from the Gulf of Cadiz along the Portuguese margin, forming a contour current with a cyclonical pattern around the PS (Rice et al. 1991; Van Aken and Becker 1996; Dorschel et al. 2007b). In the Belgica Mound Province, Dorschel et al. (2007a) and White (2007) recorded a constant northwestward directed residual bottom flow, with velocities between 5 and $15 \mathrm{~cm} \mathrm{~s}^{-1}$ originating from internal and tidal period baroclinic waves (White 2007). Peak velocities of $60 \mathrm{~cm} \mathrm{~s}^{-1}$ were measured in the Belgica Mound Province (White 2007; Dorschel et al. 2007a). Lim et al. (2018) calculated a residual current of $36-40 \mathrm{~cm} \mathrm{~s}^{-1}$ in the MM. Current-induced sedimentary structures demonstrate the action of these currents, e.g., east-west directed sediment waves, ripple marks and dunes (Foubert et al. 2011) (Online Resource 1).

Benthic foraminiferal abundance and diversity depends on the input of organic matter, oxygenation and hydrosedimentary processes at the seafloor (Jorissen et al. 2007) making them useful tools to understand past and recent CWC environments (Rüggeberg et al. 2007; Margreth et al. 2009; Schönfeld et al. 2011; Morigi et al. 2012; Stalder et al. 2015). Margreth et al. (2009) proposed a model linking specific benthic foraminiferal assemblages to sedimentary facies, which has since been compared to a number of different CWC mounds (Schönfeld et al. 2011; Morigi et al. 2012; Spezzaferri et al. 2013; Smeulders et al. 2014). The aims of this study are: (1) to assess living benthic foraminiferal diversity in sediments from the MM, (2) to identify epifaunal and infaunal benthic foraminiferal distribution patterns and compare them to facies variations and (3) to better constrain the interaction between nutrient fluxes and the coral framework.

\section{Materials and methods}

Twenty surface samples collected during Eurofleets Cruise CWC-Moira (Spezzaferri et al. 2012) on the RV Belgica (2-7 June 2012) were investigated (Fig. 1, Table 1). They were recovered using a NIOZ-type box corer $(50 \mathrm{~cm}$ diameter and a $55 \mathrm{~cm}$ penetration in sediments) equipped with a global acoustic positioning system (GAPS) for seafloor positioning (Spezzaferri et al. 2012). Sampling sites were identified in video surveys acquired during the VENTURE cruise (Wheeler and Science Party 2011).

Samples for micropaleontology were collected and processed following the FOBIMO protocol (Schönfeld et al. 2012), although no replicates were taken. Corals and other macrofauna were removed before sampling. Three subcores $(10 \mathrm{~cm}$ diameter $)$ were taken from box cores $\mathrm{BC} 26, \mathrm{BC} 34$ and BC35 and sliced down to $15 \mathrm{~cm}$ at $1 \mathrm{~cm}$ resolution. All were placed in an ethanol Rose Bengal solution (Walton 1952; Schönfeld et al. 2012). They were washed through 250, 125 and $63 \mu \mathrm{m}$ mesh sieves, dried and weighed. Residues were dry picked for Rose Bengal stained (living) and unstained (dead) benthic foraminifera. At least 300 dead individuals and all living individuals were randomly picked. Only living benthic foraminifera were investigated for the three subcores. Large clasts (e.g., 
Table 1 Sample number, coordinates, water depth and surface description of investigated box cores (Spezzaferri et al. 2012)

\begin{tabular}{lllll}
\hline Sample & Latitude $(\mathrm{N})$ & Longitude $(\mathrm{E})$ & Depth $(\mathrm{m})$ & Surface description \\
\hline BC1 & $51^{\circ} 26,433^{\prime}$ & $11^{\circ} 49,512^{\prime}$ & 1057 & Sand with dropstones \\
BC4 & $51^{\circ} 26,304^{\prime}$ & $11^{\circ} 49,385^{\prime}$ & 1062 & Coral rubble and sand \\
BC5 & $51^{\circ} 26,331^{\prime}$ & $11^{\circ} 49,402^{\prime}$ & 1069 & Coral framework and sand \\
BC10 & $51^{\circ} 29,697^{\prime}$ & $11^{\circ} 49,140^{\prime}$ & 970 & Rippled sand \\
BC14 & $51^{\circ} 26,959^{\prime}$ & $11^{\circ} 49,451^{\prime}$ & 1064 & Coral rubble and sand \\
BC17 & $51^{\circ} 26,951^{\prime}$ & $11^{\circ} 49,462^{\prime}$ & 1057 & Sand \\
BC20 & $51^{\circ} 26,560^{\prime}$ & $11^{\circ} 49,213^{\prime}$ & 1062 & Rippled sand \\
BC21 & $51^{\circ} 29,312^{\prime}$ & $11^{\circ} 49,120^{\prime}$ & 980 & Coral rubble and muddy sand, rare dropstones \\
BC22 & $51^{\circ} 30,189^{\prime}$ & $11^{\circ} 49,395^{\prime}$ & 952 & Coral rubble and muddy sand \\
BC23 & $51^{\circ} 30,213^{\prime}$ & $11^{\circ} 49,379^{\prime}$ & 951 & Sand with abundant biogenic fragments \\
BC24 & $51^{\circ} 30,227^{\prime}$ & $11^{\circ} 49,390^{\prime}$ & 942 & Coral rubble and muddy sand \\
BC25 & $51^{\circ} 30,502^{\prime}$ & $11^{\circ} 49,486^{\prime}$ & 933 & Coral rubble and muddy sand \\
BC26 & $51^{\circ} 30,519^{\prime}$ & $11^{\circ} 49,481^{\prime}$ & 949 & Coral framework and sand \\
BC28 & $51^{\circ} 30,527^{\prime}$ & $11^{\circ} 49,499^{\prime}$ & 949 & Coarse to medium sand and coral \\
BC31 & $51^{\circ} 29,689^{\prime}$ & $11^{\circ} 49,145^{\prime}$ & 962 & Coral framework and sand \\
BC32 & $51^{\circ} 29,672^{\prime}$ & $11^{\circ} 49,118^{\prime}$ & 972 & Coral framework and sand \\
BC33 & $51^{\circ} 29,672^{\prime}$ & $11^{\circ} 49,137^{\prime}$ & 962 & Coral rubble and muddy sand \\
BC34 & $51^{\circ} 29,671^{\prime}$ & $11^{\circ} 49,132^{\prime}$ & 975 & Silty sand and biogenic fragments \\
BC35 & $51^{\circ} 29,650^{\prime}$ & $11^{\circ} 49,149^{\prime}$ & 966 & Medium to fine sand and dropstones \\
BC36 & $51^{\circ} 29,657^{\prime}$ & $11^{\circ} 49,050^{\prime}$ & 970 & Sand and dropstones \\
\hline
\end{tabular}

dropstones and/or coral fragments) were also scrutinized at the stereomicroscope to record still attached specimens. Plummer cells were mounted and ordered to document all recognized species.

Living benthic foraminiferal data were standardized for $50 \mathrm{~cm}^{3}$ of sediment whereas dead benthic foraminiferal data were standardized to percentages and statistically treated separately using the software PAST 3.12 (Hammer et al. 2001). The Similarity Percentage Analysis (SIMPER) was obtained with the PRIMER 6 software (Clarke and Gorley 2006). The Diversity Shannon index was calculated for all samples. Data for non-metric MultiDimensional Scaling (nMDS) analysis were not transformed. Clusters identified in the nMDS plot, both based on the Bray-Curtis Dissimilarity, underwent a non-parametric MANOVA test (NPMANOVA) and SIMPER. The SIMPER allowed to reveal the contribution of each species to the total dissimilarity/similarity, their individual contribution to each group (Clarke and Gorley 2006), and to highlight ecological differences in benthic foraminiferal assemblages. The ratio between the average contribution of a species $\left(\bar{\delta}_{i}\right)$ and the standard deviation of the species average contribution [SD $\left.\left(\bar{\delta}_{i}\right)\right]$, defined as follows: $\bar{\delta}_{i} / \mathrm{SD}\left(\bar{\delta}_{i}\right)$ (Clarke and Gorley 2006) was used to recognize discriminating species, e.g., the higher the value, the better the species is as a discriminator.

To analyse foraminiferal distribution within the sediments, the average living depth or ALD (Jorissen et al.
1995) for the infaunal component of the assemblage was calculated following the equation:

$\mathrm{ALD}_{\mathrm{x}}=\sum_{i=0, \mathrm{x}}\left(\mathrm{n}_{\mathrm{i}} \mathrm{D}_{\mathrm{i}}\right) / \mathrm{N}$

where $x$ is the lowest boundary of the deepest sample, $n_{i}$ is the number of specimens in interval $i, D_{i}$ is the midpoint of sample interval $i$, and $N$ is the total number of individuals for all levels. Calculation of the $\mathrm{ALD}_{(6)}$ (infauna) was performed on infaunal species: Bolivina pseudopunctata, Bolivina difformis, Bulimina marginata, Globocassidulina subglobosa, Melonis barleeanum, Nonionella iridea, Nonionella labradorica, Pullenia bulloides, Pullenia subcarinata, Trifarina angulosa, Trifarina bradyi, Uvigerina mediterranea and Uvigerina peregrina. In the case of the $\mathrm{MM}$, the choice of investigated subcores enabled to decipher the main responses of the infaunal communities to surface sediment variability.

Total organic carbon (TOC) content (in weight\%) was measured on $100 \mathrm{mg}$ of surface bulk sediment by RockEval6 at the University of Lausanne.

\section{Results}

\subsection{Facies classification and description}

Facies were described on board (Spezzaferri et al. 2012; Vertino et al. 2015). Examples of the three defined facies 
are illustrated in the Online Resource 1 and in Spezzaferri et al. (2012). The living and dead coral facies is characterized by dense coral cover of live and/or dead colonies of corals together with sandy to muddy sandy sediments (Vertino et al. 2015). It is observed in box cores 4, 5, 14, 21, 22, 24, 25, 26, 28, 31, 32 and 33 (Fig. 1, Online Resource 1). Among these, two box cores (33 and 28) show contribution also from the sand and biogenic gravel facies. The sand and biogenic gravel facies is characterized by sandy to muddy sediment and/or bioclastic gravel. Sandy sediments are often rippled. This facies is present in box cores 10, 17, 20, 23 and 34 (Fig. 1, Online Resource 1). The sand and dropstones facies is characterized by sandy to muddy sediments and heterometric dropstones. This facies is represented by box cores 1, 35 and 36 (Fig. 1, Online Resource 1).

\subsection{Distribution of living benthic foraminifera}

Eighty-seven species were recognized (Online Resource 2). Multivariate analysis performed on the complete and standardized dataset reveals variations in the total number of individuals from one sample to another. Species contributing to the average dissimilarity/similarity and their individual abundances are listed in Online Resource 3.

The nMDS plot allowed to identify one main cluster (Cluster L) composed of 11 samples (Fig. 2a) and an outlier group. Cluster L groups all samples from the living coral and dead coral facies, except for BC33 that shares characteristics from the sand and biogenic gravel facies. Cluster L is hereafter referred to as the "Coral Assemblage". All nine outliers represent the sand and biogenic gravel facies, and sand and dropstone facies; except for $\mathrm{BC} 33$. The nine outlier samples are hereafter indicated as part of the "No-Coral Assemblage" (Fig. 2a).

The Coral Assemblage is characterized by the epibenthic Alabaminella weddellensis and the infaunal T. bradyi. Both species contribute to more than $15 \%$ of the total abundance. Less contributing species (from 6 to 11\%) are Hanzawaia boueana, T. angulosa, N. iridea, and G. subglobosa (Online Resource 3). Epifaunal taxa represent $44.3 \%$ (against $40.8 \%$ when coral is absent) of the entire assemblage, infaunal taxa $39.8 \%$ (against $47.1 \%$ when coral is absent). In the No-Coral Assemblage the most important species (about 19\% of the total abundance) are H. boueana and T. bradyi; other species (from 6 to 12\%) are T. angulosa, G. subglobosa, Hoeglundina elegans and Cibicides refulgens. They represent together $15.4 \%$ of the total abundance (Online Resource 3). Benthic foraminifera characterizing the living assemblage are illustrated in Fig. 3.

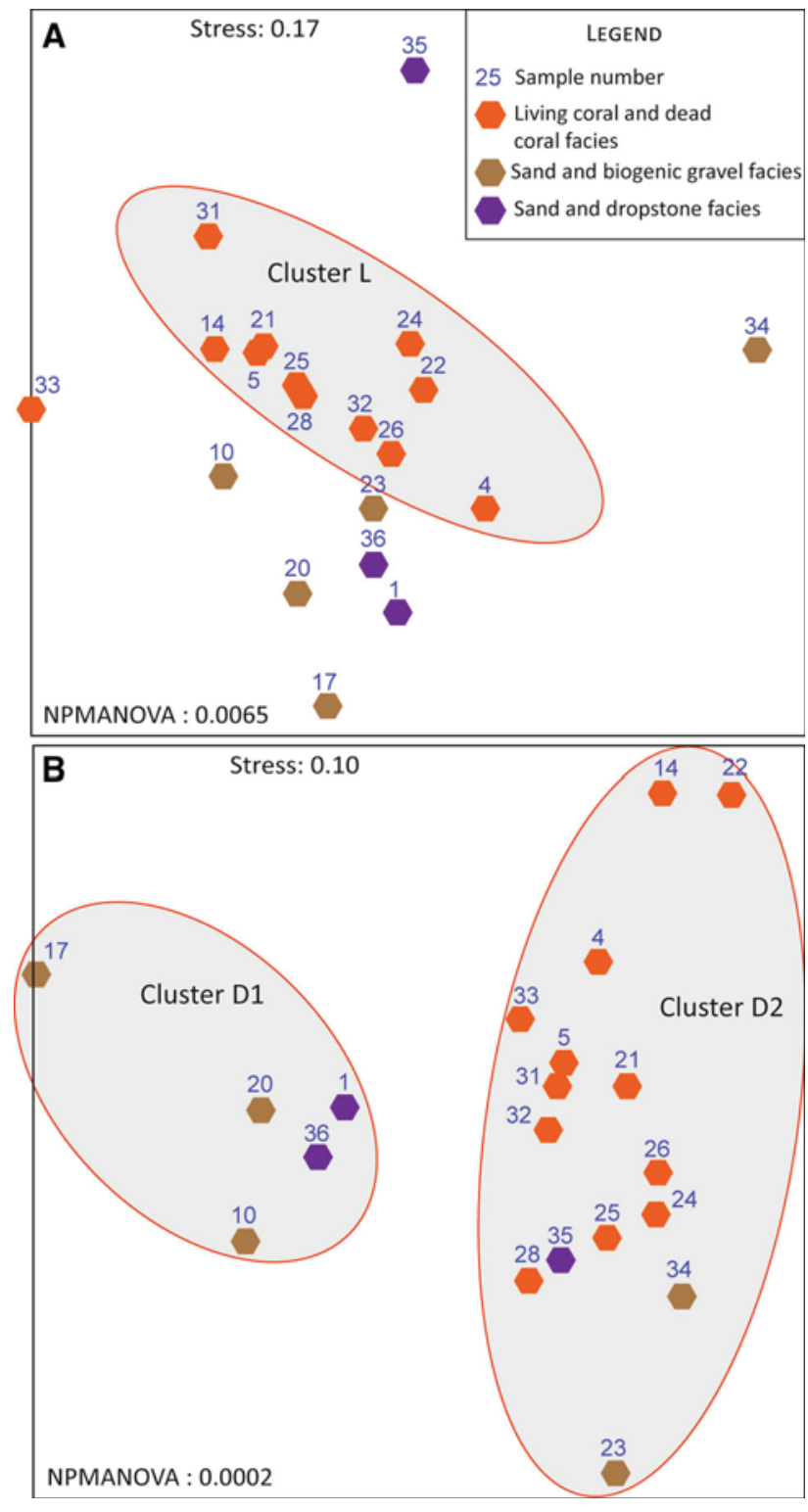

Fig. 2 Non-metric MultiDimensional Scaling (nMDS) plots based on Bray-Curtis similarity matrix of living (a) and dead (b) benthic foraminiferal assemblages. The clusters discussed in the text are represented by the grey filled ovals. Non-parametric MANOVA tests values (based on Bray-Curtis dissimilarity measures) are indicated along with the $2 \mathrm{D}$ stress values

Alabaminella weddellensis and $N$. iridea have the highest $\bar{\delta}_{i} / \mathrm{SD}\left(\bar{\delta}_{i}\right)$ ratios, demonstrating that they are good discriminating species between the Coral and No-Coral assemblages. The Coral Assemblage is more diverse than the No-Coral Assemblage (2.85 and 2.43 Shannon index, respectively) and yields approximately double the number of individuals $\left(230 / 50 \mathrm{vs} 117 / 50 \mathrm{~cm}^{3}\right)$.

The non-parametric MANOVA test, used to test the separation between the Coral Assemblage and the NoCoral Assemblage produced a $p$ value of 0.0065 (Fig. 2a). 

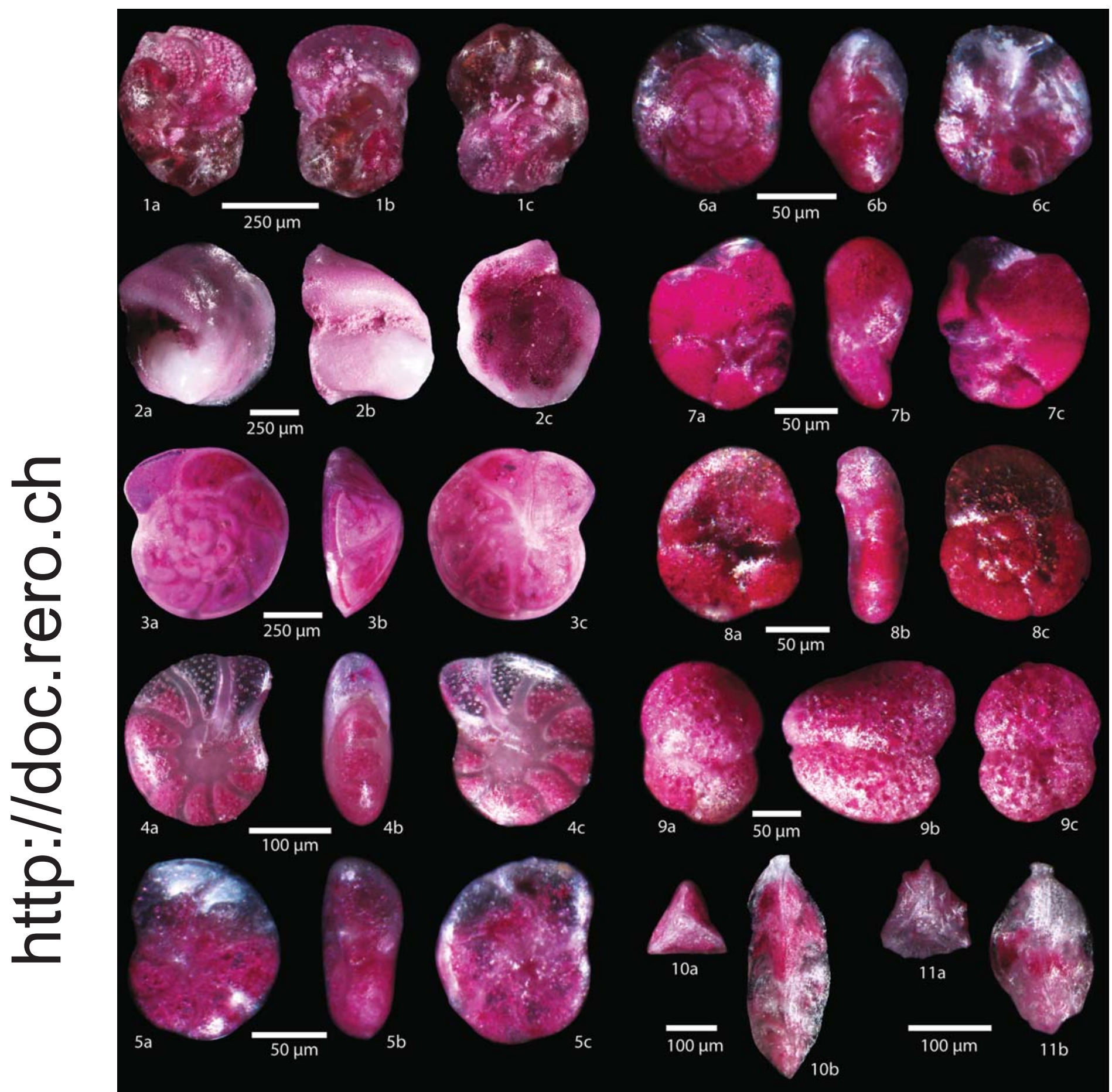

Fig. 3 Important living (stained) benthic foraminifera species identified in the Moira Mounds: 1a-c Discanomalina coronata (Parker and Jones, 1857). 2a-c Cibicides refulgens (de Monfort, 1808). 3ac Hoeglundina elegans (d'Orbigny, 1826). 4a-c Melonis barleeanum (Williamson, 1858). 5a-c Hanzawaia boueana (d'Orbigny, 1846).

\subsection{Distribution of dead benthic foraminifera}

One hundred and forty-three dead benthic foraminiferal species were recognized (Online Resource 2). The nMDS 6a-c Alabaminella weddellensis (Saidova, 1975). 7a-c Nonionella iridea (Heron-Allen and Earland, 1932). 8a-c Paratrochammina globorotaliformis (Zheng, 1988). 9a-c Adercotryma wrightii (Brönnimann and Whittaker, 1987). 10a-c Trifarina bradyi (Cushman, 1923). 11a-c Trifarina angulosa (Williamson, 1858)

allows to separate two clusters: Cluster D1 (5 samples) and Cluster D2 (15 samples) (Fig. 2b). Cluster D1 groups three samples from the sand and biogenic gravel facies and two from the sand and dropstone facies. Cluster D1 groups the 
samples that show clear rippled surfaces (BC20 and 10). Cluster D2 groups the remaining samples, essentially associated to the living coral and dead coral facies (Fig. 2b).

Cibicides kullenbergi, Sigmoilopsis schlumbergeri and Cassidulina teretis dominate Cluster D1 (contribution values above 19\%, Online Resource 3). Cibicides kullenbergi is the most dominant species (over $28 \%$ of the average similarity). In Cluster D2, C. teretis and C. kullenbergi are also dominant (both contributing over 10\%). However, in contrast with Cluster D1, C. teretis contributes more than $C$. kullenbergi (22 vs $10.9 \%$ ). Less contributing species (between 6 and 7\%) are Cassidulina crassa, Elphidium subarcticum, S. schlumbergeri and D. coronata (Online Resource 3).

Sigmoilopsis schlumbergeri and C. kullenbergi strongly contribute to the average dissimilarity (33.2\%) between Cluster D1 and D2 (Online Resource 3). Sigmoilopsis schlumbergeri and $C$. kullenbergi also show high $\bar{\delta}_{i} / \operatorname{SD}\left(\bar{\delta}_{i}\right)$ values, together with $C$. crassa, Bolivina spathulata and $U$. mediterranea. The dissimilarity analysis confirms that $C$. kullenbergi and S. schlumbergeri are the species distinguishing the best between Cluster D1 and D2. Uvigerina mediterranea, more abundant in Cluster D1, and $B$. spathulata and C. crassa, more abundant in Cluster D2, also contribute to a lesser extent to the separation between the two clusters.

Cluster D1 has a lower Shannon Diversity Index value (2.5) than cluster D2 (3.1). The non-parametric MANOVA test, comparing Cluster D1 with Cluster D2, produced a p-value of 0.0002 (Fig. 2b).

\subsection{Distribution of foraminifera in the sediments}

Forty-four species were identified in the three subcores (Online Resource 2); the distribution of dominant species is illustrated in Fig. 4. Foraminiferal abundances rapidly decline downcore. However, in the presence of corals (BC26), foraminifera are more abundant in the first two centimetres of sediment, reaching over 350 individuals/ $50 \mathrm{~cm}^{3}$ and accounting for approximately $93 \%$ of the total assemblage (Fig. 4). In absence of corals, benthic foraminifera are rarer in the first two centimetres, ranging from $150 / 50 \mathrm{~cm}^{3}$ (74\% of the total assemblage) for BC35 to $35 / 50 \mathrm{~cm}^{3}$ (71.6\% of the total assemblage) for BC34 (Fig. 4). Infaunal species represent approximately $47 \%$ of the assemblage in $\mathrm{BC} 26$ whereas they represent approximately $60 \%$ in BC34 and only $21 \%$ in BC35. Epibenthic species are mainly represented by $H$. boueana, Cibicides aravaensis, $C$. refulgens and $C$. kullenbergi, whereas infaunal species are mainly represented by $T$. angulosa, $T$. bradyi, M. barleeanum and B. pseudopunctata (Fig. 4).
Epifaunal species, such as A. weddellensis or H. boueana, are found in sediments at $6 \mathrm{~cm}$ downcore in BC26 and $3 \mathrm{~cm}$ downcore in BC34 and BC35, respectively (Fig. 4).

Although shallow in all three subcores, the $\mathrm{ALD}_{(6)}$ (infauna) is slightly shallower in presence of corals $\left[\mathrm{ALD}_{(6)}=1.07 \mathrm{~cm}\right]$ and slightly deeper in absence of corals $\left[\mathrm{ALD}_{(6)}=1.60 \mathrm{~cm}\right.$ for $\mathrm{BC} 34, \mathrm{ALD}_{(6)}=2.04 \mathrm{~cm}$ for BC35] (Fig. 5).

\subsection{Total organic carbon (TOC) in the sediments}

The TOC content shows overall low values, ranging from 0.02 to $0.29 \%$ (Fig. 6). No distinct relation between TOC content, facies and benthic foraminiferal assemblages is observed (Fig. 6).

\section{Discussion}

The distribution of benthic foraminifera follows a complex interplay between oxygenation and food availability, which are related to the depth in the sediments and current dynamics (Fontanier et al. 2002; Schönfeld 2002; Jorissen et al. 2007). It is well known that bottom currents shape CWC mounds (Dorschel et al. 2005; Van Rooij et al. 2007; Huvenne et al. 2009b; Foubert et al. 2011; Hebbeln et al. 2016) and that the presence of coral build-ups may locally affect sedimentation (Foubert et al. 2011). This interaction creates distinct ecological niches for benthic foraminifera and other organisms (Roberts et al. 2006; Margreth et al. 2009).

\subsection{Facies associated to the living benthic foraminiferal assemblage}

Stefanoudis et al. (2016) demonstrated that abyssal hills influence benthic foraminiferal diversity. Similarly, the topographic highs provided by the small MM may induce higher diversity. Food sources available to foraminifera and produced by the diverse macro-organisms living within CWCs, e.g., the coral mucus itself (Wild et al. 2009), may also account for their higher diversity compared to adjacent areas. On Galway Mound, living epifauna in CWCs is more abundant (Schönfeld et al. 2011) than in the MM, where epifaunal and infaunal species are equally distributed suggesting less differentiated environments than on Galway Mound. However, Schönfeld et al. (2011) only studied the $>250 \mu \mathrm{m}$ size fraction, thus underestimating small infaunal species (N. iridea, T. bradyi, T. angulosa, Bulimina spp. and Bolivina spp.). This different approach may account for discrepancies with the present study.

Diversity patterns in the MM also disagree with Morigi et al. (2012), who observed extremely low diversity in absence of corals on the Rockall Bank. The high currents 

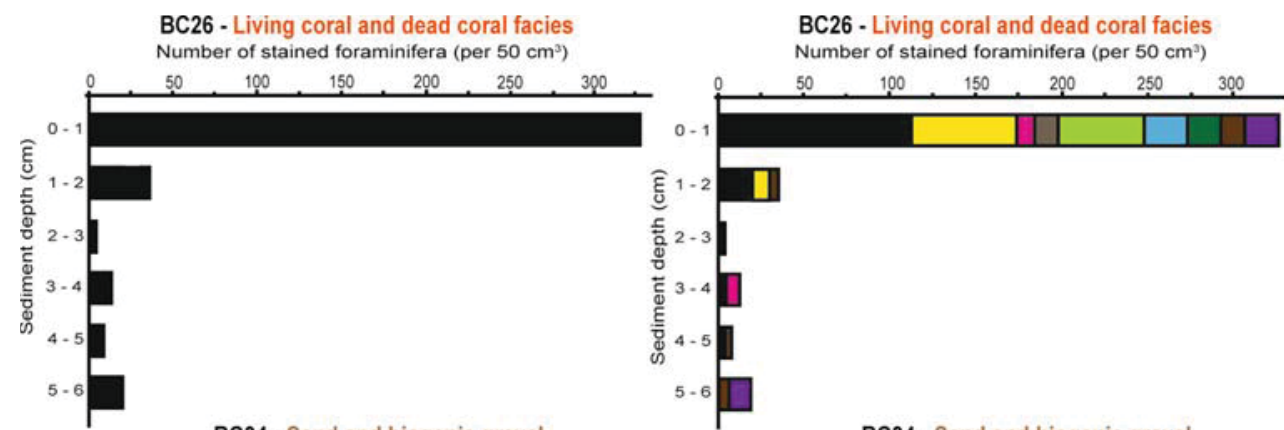

Legend

BC34 - Sand and biogenic gravel

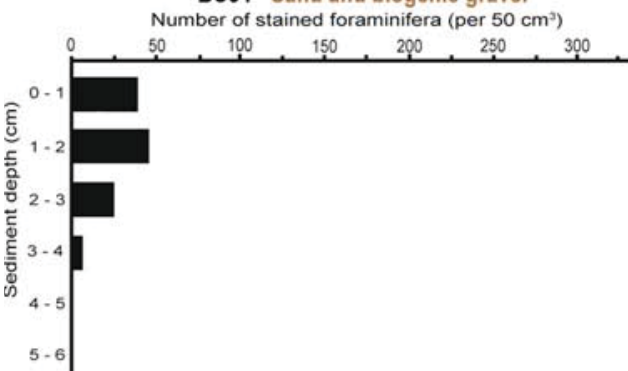

BC34 - Sand and biogenic grave

Number of stained foraminifera (per $50 \mathrm{~cm}^{3}$ )
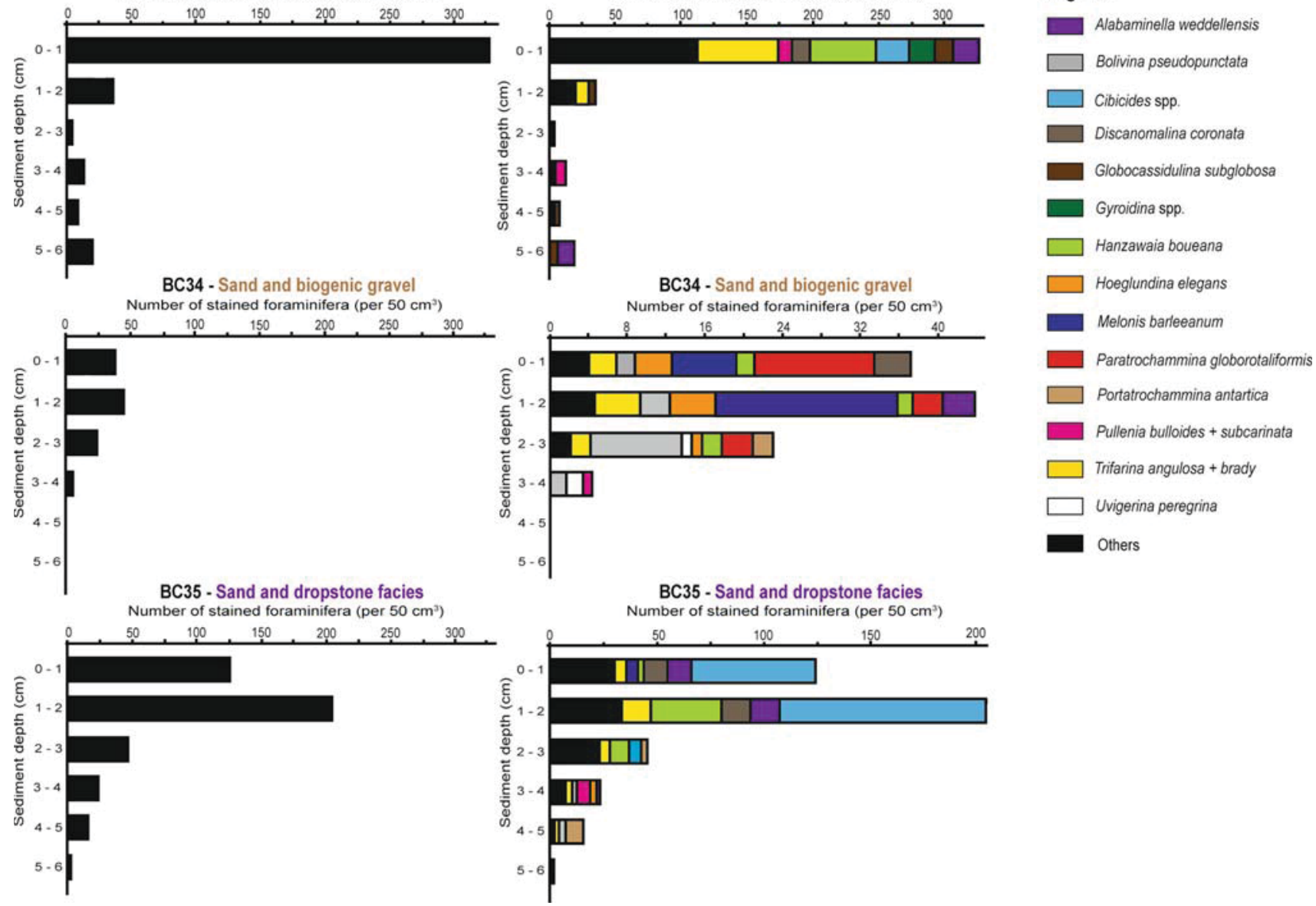

foraminiferal distribution in the sediments from 0 to $6 \mathrm{~cm}$ depth,

Fig. 4 Foraminiferal distribution in the sediments of box cores (BC) 26, 34 and 35. Left: total foraminiferal abundance from 0 to $6 \mathrm{~cm}$ depth, $\mathrm{x}$ axis is identical for all three samples. Right: dominant
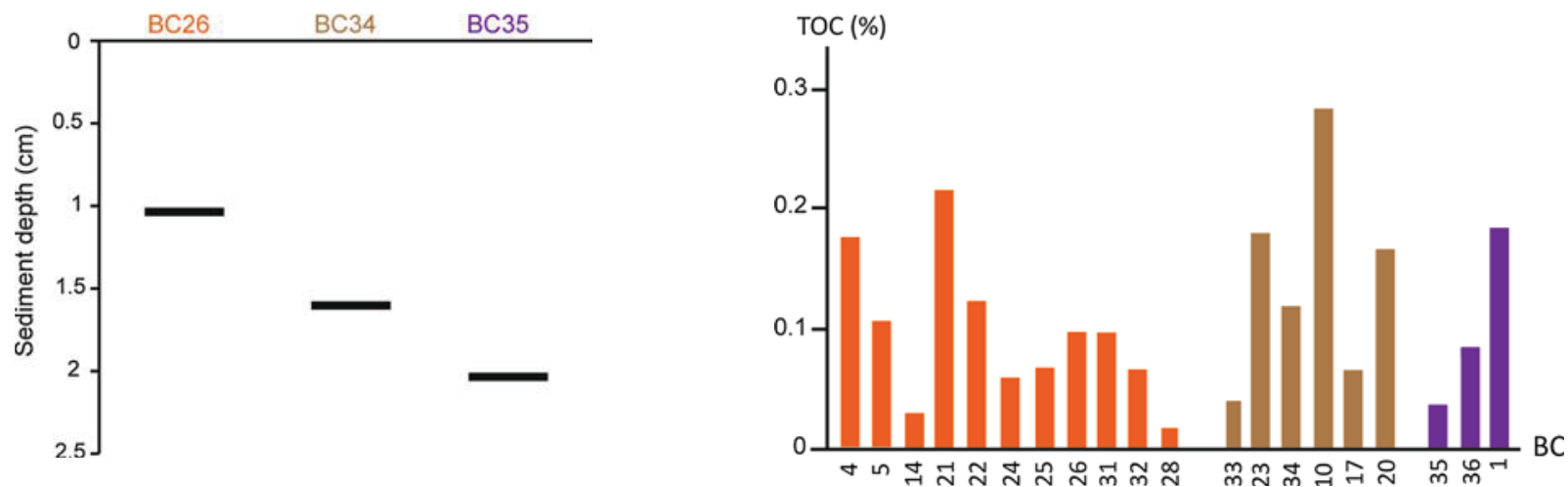

Fig. 5 Average living depth (6) (ALD) of infaunal foraminifera in box cores (BC) 26, 34 and 35. BC26: living coral and dead coral facies, BC34: sand and biogenic gravel facies, BC35: sand and dropstone facies

recorded at the Rockall Bank (from 30 to $75 \mathrm{~cm} \mathrm{~s}^{-1}$ ) and the lack of investigation of large sized debris for attached foraminifera are two explanations offered by Morigi et al. (2012) for the low diversity they observed. The abundance

Fig. 6 Total organic carbon (TOC) content in box core (BC) surface sediments. Orange bars: living coral and dead coral facies; brown bars: sand and biogenic gravel facies; purple bars: sand and dropstone facies

of infaunal species in the MM confirms the observations of Margreth et al. (2009) who also reported typical infaunal species on-mound. 
The high abundance of the epifaunal phytodetritusfeeding A. weddellensis (Gooday 1993; Fariduddin and Loubere 1997; Gooday and Hughes 2002; Murray 2006; Sun et al. 2006) in the Coral Assemblage, together with the infaunal phytodetritus-feeding N. iridea, (Duchemin 2005; Murray 2006; Duffield et al. 2015), suggests that CWCs can trap phytodetritus that would otherwise not settle in an open setting, due to the intense currents (Fig. 7). Thus, coral and associated benthic foraminifera thrive in areas where currents are sufficiently strong to deliver phytodetritus, but are not strong enough to prevent the particulate organic matter from settling. This hypothesis is supported by Lim et al. (2017) who noticed that on the Piddington Mound in the MM area, living corals are concentrated on the lee-side of the mound. The settling of corals in these favourable areas would stabilize sediment waves and through sediment baffling, promote mound growth (Dorschel et al. 2005; Mienis et al. 2007; Huvenne et al. 2009a; Eisele et al. 2014).

High abundances of $N$. iridea and A. weddellensis in the Coral Assemblage may also be related to higher phytodetritus input shortly before sampling in the first week of June. Although blooms mainly occur during early to midspring, they may also extend to late spring in the North
East Atlantic (LeBlanc et al. 2009; Van Oostende et al. 2012), producing brief high abundances of $N$. iridea and $A$. weddellensis that may not reflect the environment over a longer period of time.

In absence of corals, $C$. refulgens, associated to the sandwave facies by Margreth et al. (2009), is observed attached to dropstones in open settings, in agreement with Schönfeld et al. (2011).

\subsection{Facies associated to the dead benthic foraminiferal assemblage}

Dead benthic foraminiferal assemblages on the MM resemble those associated to the sandwave facies identified by Margreth et al. (2009). Sigmoilopsis schlumbergeri and C. kullenbergi dominate Cluster D1. Sigmoilopsis schlumbergeri positively correlates with high organic matter in the Adriatic Sea (Jorissen 1987) and in CWC environments it is considered as preferring the sandwave facies (Margreth et al. 2009). Cibicides kullenbergi dwells on shallow hard-substrates and mud (e.g., Corliss 1985; Schmiedl et al. 2000). It is associated to the off-mound facies in the PS, characterized by sediments containing sand-sized foraminifera, echinoids, molluscs and

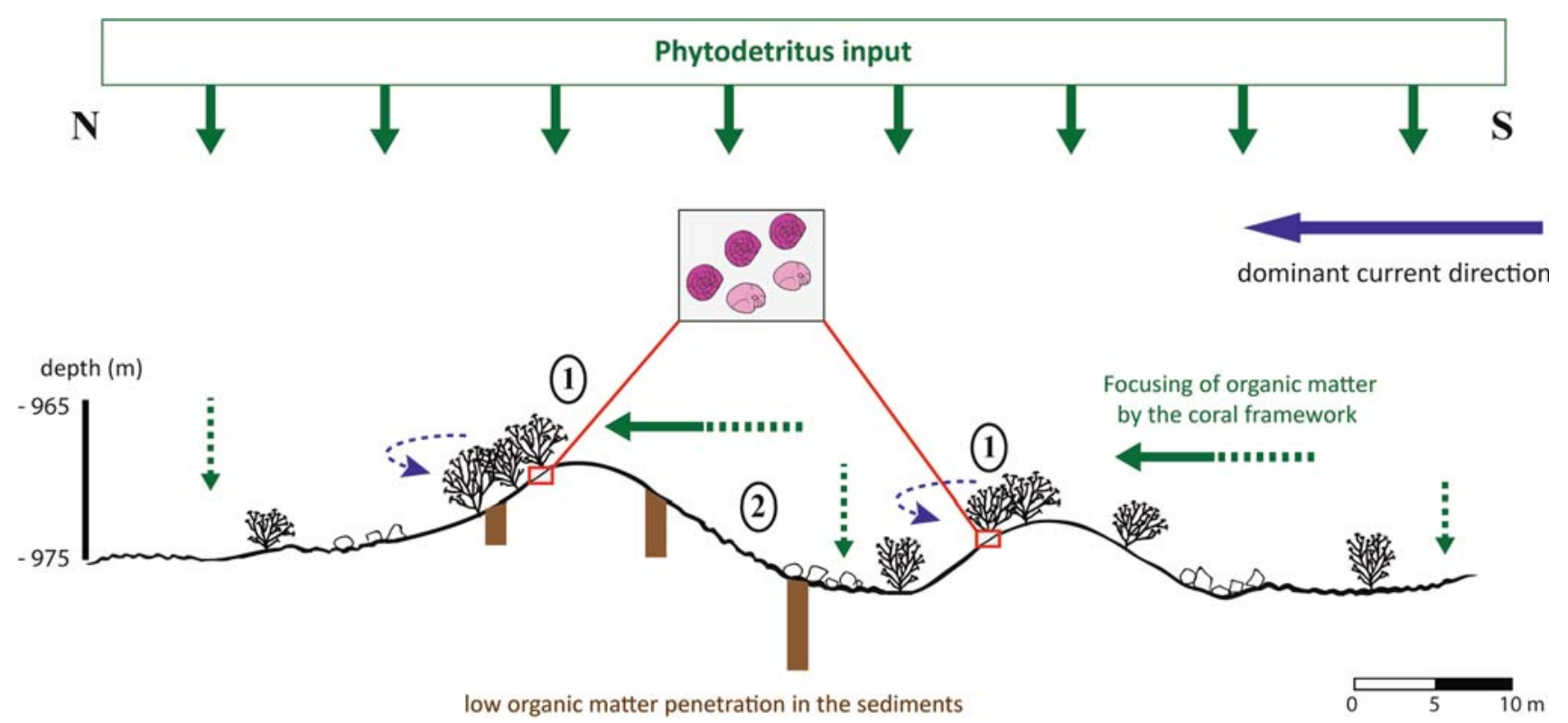

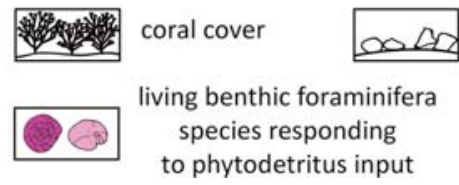

dropstones

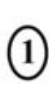
1) Arrival of more organic matter, higher consumption at surface/water interface

Average Living Depth (ALD) (infauna)

(2) Arrival of less organic matter,
lower consumption at surface/water interface
Fig. 7 Simplified ecological model of the Moira Mounds. This model represents typical mound sizes observed in the Moira Mounds. Coral distribution on the mounds is based on observations made by Lim et al. (2017). Only the mounds are to scale. Average living $\operatorname{depth}_{(6)}$ (infauna) (ALD) are not to scale but proportions have been respected 
terrigenous components (Margreth et al. 2009). The relatively high contribution and the high $\bar{\delta}_{i} / \mathrm{SD}\left(\bar{\delta}_{i}\right)$ value of $U$. mediterranea, a shallow infaunal species typical of offmound settings in the PS (Margreth et al. 2009; Schönfeld et al. 2011), would confirm that Cluster D1 can be related to the sandwave, dropstone and off-mound facies of Margreth et al. (2009). This observation implies different spatial distributions of benthic foraminiferal assemblages between large and small mounds. The facies model developed by Margreth et al. (2009) is based on large mounds where foraminiferal distribution is consistent with facies that develop over a large area. The MM are considerably smaller and their sedimentary facies develop within meters and/or centimetres, creating reduced microenvironments. Therefore, Cluster D1 cannot be matched to a specific facies described for large mounds; it represents instead a relatively diverse open environment.

Following the classification of Margreth et al. (2009), the higher contribution of $D$. coronata and B. spathulata in Cluster D2 implies a closer relationship to the living coral and sandwave facies. High abundances of $C$. crassa and $G$. subglobosa are associated to CWCs in dead assemblages from the Rockall Bank compared to off-mound settings (Morigi et al. 2012). This would suggest a close affinity of Cluster D2 to the coral facies (Fig. 2b).

\subsection{Living foraminiferal assemblages in sediments}

Several studies show that infaunal foraminiferal assemblages are related to food and oxygen availability (e.g., Jorissen et al. 1995; Fontanier et al. 2002; Hess et al. 2005). The TROX-model (Jorissen et al. 1995) suggests that in eutrophic areas, oxygen is the limiting factor, whereas food is the limiting factor in oligotrophic areas. The deepest penetration of benthic foraminifera in sediments is in mesotrophic conditions, where neither oxygen nor nutrient values are at a minimum. Based on infaunal foraminiferal distribution (Fig. 4) and the low TOC content in the sediments of the MM (Fig. 6), the main limiting factor appears to be food availability. In the MM benthic fauna concentrates in the upper two centimetres of sediment (Fig. 4) and consists of shallow infauna, e.g., T. angulosa and H. elegans (Hess and Jorissen 2009; Duros et al. 2011) or shallow to intermediate infaunal e.g., M. barleeanum, $U$. peregrina and Gyroidina spp. (Schmiedl et al. 2000; Fontanier et al. 2008). The slightly shallower $\mathrm{ALD}_{(6)}$ (infauna) in the presence of corals (Fig. 5) would demonstrate that food is rapidly consumed by the filtering suspension feeders (Wehrmann et al. 2009), causing limited accumulation down in the sediment, or alternatively, that it is oxidized in the upper part of the sediments. Low food availability in the sediment would encourage shallow infaunal species such as T. angulosa and T. bradyi (e.g., Duros et al. 2011) and shallow to intermediate infaunal species such as Gyroidina spp. (Fontanier et al. 2002) to migrate upwards. The high foraminiferal abundance only in the first centimetre of sediment (Fig. 4), may suggest decoupling between the productive coral bearing sediments and the sediments below, the filtering suspension feeders acting as a sink for organic matter (Wehrmann et al. 2009).

Dropstones in BC35 and coral framework in BC26 offer suitable substrate for epibenthic species e.g., Cibicides spp. (Fig. 4), whereas the abundance of infauna in BC34 can be related to the absence of both dropstones and coral (Fig. 4). The infaunal Pullenia spp., H. elegans and B. pseudopunctata (Geslin et al. 2004; Murray 2006; Wollenburg and Mackensen 2009) are found below the first two/three centimetres of sediment (Fig. 4). The relative high abundances of $M$. barleeanum in the upper two centimetres, together with Paratrochammina globorotaliformis, characterizes BC34 (Fig. 4). Melonis barleeanum has been described as an intermediate infaunal species dependent on aerobic and anaerobic bacterial stocks that degrade refractory organic matter (Schmiedl et al. 2000; Fontanier et al. 2002, 2005). The ecology of $P$. globorotaliformis is not well constrained, however, a related species, Paratrochammina haynesi, is documented attached to gravel and shells, in crevices or ribs in current swept areas such as channels (Murray and Alve 1993; Murray 2006), suggesting similar preferences for $P$. globorotaliformis in the MM. The intense currents that sweep the MM may confirm a similar ecological preference. Box core 34 is situated on the south current facing side of the Piddington Mound (Lim 2017), where strong currents and the absence of baffling organisms (e.g., corals) may create a habitat relatively depleted in fresh organic matter. This may favour the proliferation of M. barleeanum and P. globorotaliformis, whilst reducing total foraminiferal abundance.

Foraminifera can quickly respond to changes in the microhabitat (Fontanier et al. 2008). Kiriakoulakis et al. (2004) propose that large echiuran worms may produce intense bioturbation in the Darwin Mounds. Bioturbation may deeply shape microhabitats where some benthic species can adapt to live after transport (Fontanier et al. 2008; Duros et al. 2011). In the Whittard Canyon, Duros et al. (2011) observed the shallow infaunal $T$. angulosa and $B$. spathulata at $10 \mathrm{~cm}$ sediment depth, living in the more oxygenated internal surface of burrows. In $\mathrm{BC} 35, T$. angulosa occurs from the surface down to a depth of $5 \mathrm{~cm}$ in the sediment. In contrast, Pullenia spp. prefers a specific depth from 3 to $4 \mathrm{~cm}$ in the sediments (Fig. 4). The continuous presence of $T$. angulosa at different depths could confirm the ability of this species to colonize burrows. The presence of G. subglobosa and $A$. weddellensis in the sediments between 5 and $6 \mathrm{~cm}$ 
depth in BC26 may also be the result of bioturbation. Indeed, A. weddellensis is an epibenthic species (Gooday 1993; Gooday and Hughes 2002; Murray 2006; Sun et al. 2006), whilst $G$. subglobosa is as a shallow infaunal species living in the first two centimetres of sediment (Mackensen and Douglas 1989; Enge et al. 2012). Remobilization of sediments by currents could also displace benthic foraminifera in the sediments. Huvenne et al. (2009a) recognized the possible existence of "benthic storms" (Hollister and McCave 1984) with current velocities reaching up to $30 \mathrm{~cm} \mathrm{~s}^{-1}$ in the Darwin Mounds (Northern Rockall Trough). Lim (2017) calculated velocities of up to $40 \mathrm{~cm} \mathrm{~s}^{-1}$ in the MM region. In such high-energy environments, currents could easily displace the upper first centimetres of sediment and mobilize foraminifera.

\section{Conclusion}

This study suggests that high abundances of living $N$. iridea and $A$. weddellensis can be related to the coral framework's ability to capture phytodetritus in the Moira Mounds. Corals and associated benthic foraminifera thrive where currents are strong enough to mobilize nutrients, but not so strong as to be harmful for the ecosystem. This equilibrium may trigger mound growth through sediment baffling. Foraminifera are essentially present in surface sediments due to higher food availability. Benthic foraminiferal distribution in depth is shallow and is possibly impacted by bioturbation and the strong currents influencing the area. Higher abundances and diversity of living benthic foraminifera are observed in the living and dead coral facies. The Moira Mounds differ from larger adjacent mounds by lower spatial variability in foraminiferal assemblages. Clear facies distinction can only be based on living foraminiferal assemblages, and can only be made according to presence vs absence of corals.

Acknowledgements We acknowledge the Captain, crew and scientific party of the RV Belgica cruise no. 2012/16. The Moira Mounds were sampled during the cruise funded by the European Union Seventh Framework Programme (FP7/2007-2013), under the EUROFLEETS Grant Agreement no. 228344. This study is funded by the Swiss National Science Foundation (Project no. FN-200020_153125). We thank Thierry Adatte for performing the Rock-Eval pyrolysis. Furthermore, we warmly thank Dr. Joachim Schönfeld and two anonymous reviewers for their constructive comments which improved the quality of this work.

\section{References}

Beyer, A., Schenke, H. W., Klenke, M., \& Niederjasper, F. (2003). High resolution bathymetry of the eastern slope of the Porcupine Seabight. Marine Geology, 198(1-2), 27-54.
Clarke, K. R., \& Gorley, R. N. (2006). PRIMER v6: User manual/tutorial. Plymouth: PRIMER-E.

Corliss, B. H. (1985). Microhabitats of benthic foraminifera within deep-sea sediments. Nature, 314, 435-438.

De Mol, B., Van Rensbergen, P., Pillen, S., Van Herreweghe, K., Van Rooij, D., McDonnell, A., et al. (2002). Large deep-water coral banks in the Porcupine Basin, southwest of Ireland. Marine Geology, 188(1), 193-231.

Dorschel, B., Hebbeln, D., Foubert, A., White, M., \& Wheeler, A. J. (2007a). Hydrodynamics and cold-water coral facies distribution related to recent sedimentary processes at Galway Mound west of Ireland. Marine Geology, 244(1-4), 184-195.

Dorschel, B., Hebbeln, D., Rüggeberg, A., \& Dullo, C. (2007b). Carbonate budget of a cold-water coral carbonate mound: Propeller Mound, Porcupine Seabight. International Journal of Earth Sciences, 96(1), 73-83.

Dorschel, B., Hebbeln, D., Rüggeberg, A., Dullo, W., \& Freiwald, A. (2005). Growth and erosion of a cold-water coral covered carbonate mound in the Northeast Atlantic during the Late Pleistocene and Holocene. Earth and Planetary Science Letters, 233(1-2), 33-44.

Duchemin, G. (2005). Living benthic foraminifera from "la Grande Vasière", French Atlantic continental shelf: Faunal composition and microhabitats. The Journal of Foraminiferal Research, 35(3), 198-218.

Duffield, C. J., Hess, S., Norling, K., \& Alve, E. (2015). The response of Nonionella iridea and other benthic foraminifera to "fresh" organic matter enrichment and physical disturbance. Marine Micropaleontology, 120, 20-30.

Duros, P., Fontanier, C., Metzger, E., Pusceddu, A., Cesbron, F., de Stigter, H. C., et al. (2011). Live (stained) benthic foraminifera in the Whittard Canyon, Celtic margin (NE Atlantic). Deep Sea Research Part I, 58, 128-146.

Eisele, M., Frank, N., Wienberg, C., Titschack, J., Mienis, F., Beuck, L., et al. (2014). Sedimentation patterns on a cold-water coral mound off Mauritania. Deep Sea Research Part II: Topical Studies in Oceanography, 99, 307-315.

Enge, A. J., Kucera, M., \& Heinz, P. (2012). Diversity and microhabitats of living benthic foraminifera in the abyssal Northeast Pacific. Marine Micropaleontology, 96-97, 84-104.

Fariduddin, M., \& Loubere, P. (1997). The surface ocean productivity response of deeper water benthic foraminifera in the Atlantic Ocean. Marine Micropaleontology, 32, 289-310.

Ferdelman, T. G., Kano, A., Williams, T., Henriet, J.-P., \& The Expedition 307 Scientists. (2005). Modern carbonate mounds: Porcupine drilling. IODP preliminary report (p. 307).

Fink, H. G., Wienberg, C., De Pol-Holz, R., Wintersteller, P., \& Hebbeln, D. (2013). Cold-water coral growth in the Alboran Sea related to high productivity during the Late Pleistocene and Holocene. Marine Geology, 339, 71-82.

Fontanier, C., Jorissen, F. J., Chaillou, G., Anschutz, P., Grémare, A., \& Griveaud, C. (2005). Live foraminiferal faunas from a $2800 \mathrm{~m}$ deep lower canyon station from the Bay of Biscay: Faunal response to focusing of refractory organic matter. Deep Sea Research Part I: Oceanographic Research Papers, 52(7), $1189-1227$.

Fontanier, C., Jorissen, F. J., Lansard, B., Mouret, A., Buscail, R., Schmidt, S., et al. (2008). Live foraminifera from the open slope between Grand Rhône and Petit Rhône Canyons (Gulf of Lions, NW Mediterranean). Deep Sea Research Part I: Oceanographic Research Papers, 55(11), 1532-1553.

Fontanier, C., Jorissen, F. J., Licari, L., Alexandre, A., Anschutz, P., \& Carbonel, P. (2002). Live benthic foraminiferal faunas from the Bay of Biscay: Faunal density, composition, and microhabitats. Deep Sea Research Part I: Oceanographic Research Papers, 49(4), 751-785. 
Foubert, A., Depreiter, D., Beck, T., Maignien, L., Pannemans, B., Norbert, F., et al. (2008). Carbonate mounds in a mud volcano province off north-west Morocco: Key to processes and controls. Marine Geology, 248, 74-96.

Foubert, A., \& Henriet, J.-P. (2009). Nature and significance of the recent carbonate mound record. Lecture notes in earth sciences (Vol. 126). Berlin: Springer.

Foubert, A., Huvenne, V. A. I., Wheeler, A., Kozachenko, M., Opderbecke, J., \& Henriet, J.-P. (2011). The Moira Mounds, small cold-water coral mounds in the Porcupine Seabight, NE Atlantic: Part B-Evaluating the impact of sediment dynamics through high-resolution ROV-borne bathymetric mapping. Marine Geology, 282(1-2), 65-78.

Freiwald, A., Fossa, J. H., Grehan, A., Koslow, T., \& Roberts, J. M. (2004). Cold-water coral reefs: Out of sight-no longer out of mind. Berlin: Springer.

Freiwald, A., Hühnerbach, V., Lindberg, B., Wilson, J. B., \& Campbell, J. (2002). The Sula reef complex, Norwegian Shelf. Facies, 47(1), 179-200.

Geslin, E., Heinz, P., Jorissen, F., \& Hemleben, C. (2004). Migratory responses of deep-sea benthic foraminifera to variable oxygen conditions: Laboratory investigations. Marine Micropaleontology, 53(3-4), 227-243.

Gooday, A. J. (1993). Deep-sea benthic foraminiferal species which exploit phytodetritus: Characteristic features and controls on distribution. Marine Micropaleontology, 22(3), 187-205.

Gooday, A. J., \& Hughes, J. A. (2002). Foraminifera associated with phytodetritus deposits at a bathyal site in the northern Rockall Trough (NE Atlantic): Seasonal contrasts and a comparison of stained and dead assemblages. Marine Micropaleontology, 46, $83-110$.

Hammer, Ø., Harper, D. A. T., \& Ryan, P. D. (2001). Past: Paleontological statistics software package for education and data analysis. Palaeontologia Electronica, 4(1), 1-9.

Hebbeln, D., Van Rooij, D., \& Wienberg, C. (2016). Good neighbours shaped by vigorous currents: Cold-water coral mounds and contourites in the North Atlantic. Marine Geology, 378, $171-185$.

Hess, S., \& Jorissen, F. J. (2009). Distribution patterns of living benthic foraminifera from Cap Breton canyon, Bay of Biscay: Faunal response to sediment instability. Deep Sea Research Part I: Oceanographic Research Papers, 56(9), 1555-1578.

Hess, S., Jorissen, F. J., Venet, V., \& Abu-Zied, R. (2005). Benthic foraminiferal recovery after recent turbidite deposition in Cap Breton Canyon (Bay of Biscay). Journal of Foraminifera Research, 35, 114-129.

Hollister, C. D., \& McCave, I. N. (1984). Sedimentation under deepsea storms. Nature, 309, 220-225.

Hovland, M., Croker, P. F., \& Martin, M. (1994). Fault-associated seabed mounds (carbonate knolls?) off western Ireland and north-west Australia. Marine and Petroleum Geology, 11(2), 232-246.

Huvenne, V. A. I., Masson, D. G., \& Wheeler, A. J. (2009a). Sediment dynamics of a sandy contourite: The sedimentary context of the Darwin cold-water coral mounds, Northern Rockall Trough. International Journal of Earth Sciences, 98(4), 865-884

Huvenne, V. A. I., Van Rooij, D., De Mol, B., Thierens, M., O'Donnell, R., \& Foubert, A. (2009b). Sediment dynamics and palaeo-environmental context at key stages in the challenger cold-water coral mound formation: Clues from sediment deposits at the mound base. Deep Sea Research Part I: Oceanographic Research Papers, 56(12), 2263-2280.

Jorissen, F. J. (1987). Benthic foraminifera from the Adriatic Sea; principles of phenotypic variation (Vol. 37). Utrecht Micropaleontological Bulletins.
Jorissen, F. J., de Stigter, H. C., \& Widmark, J. G. (1995). A conceptual model explaining benthic foraminiferal microhabitats. Marine Micropaleontology, 26(1-4), 3-15.

Jorissen, F. J., Fontanier, C., \& Thomas, E. (2007). Paleoceanographical proxies based on deep-sea benthic foraminiferal assemblage characteristics. In C. Hillaire-Marcel, \& A. de Vernal (Eds.), Proxies in late cenozoic paleoceanography: Pt. 2: Biological tracers and biomarkers (vol. 1, no. 7, pp. 263-326). Elsevier.

Kiriakoulakis, K., Bett, B., White, M., \& Wolff, G. A. (2004). Organic biogeochemistry of the Darwin Mounds, a deep-water coral ecosystem, of the NE Atlantic. Deep Sea Research Part I: Oceanographic Research Papers, 51(12), 1937-1954.

LeBlanc, K., Hare, C. E., Feng, Y., Berg, G. M., DiTullio, G. R., Neeley, A., et al. (2009). Distribution of calcifying and silicifying phytoplankton in relation to environmental and biogeochemical parameters during the late stages of the 2005 North East Atlantic Spring Bloom. Biogeosciences, 6, 2155-2179.

Lim, A. (2017). Spatio-temporal patterns and controls on cold-water coral reef development: The Moira Mounds, Porcupine Seabight, offshore Ireland. Ph.D. dissertation, University College Cork, Cork, Ireland.

Lim, A., Huvenne, V. A. I., Vertino, A., Spezzaferri, S., \& Wheeler, A. J. (2018). New insights on coral mound development from groundtruthed high-resolution ROV-mounted multibeam imaging. Marine Geology, 403, 225-237.

Lim, A., Wheeler, A. J., \& Arnaubec, A. (2017). High-resolution facies zonation within a cold-water coral mound: The case of the Piddington Mound, Porcupine Seabight, NE Atlantic. Marine Geology, 390, 120-130.

Lo Iacono, C., Gràcia, E., Ranero, C. R., Emelianov, M., Huvenne, V. A. I., Bartolomé, R., et al. (2014). The West Melilla cold water coral mounds, Eastern Alboran Sea: Morphological characterization and environmental context. Deep Sea Research Part II: Topical Studies in Oceanography, 99, 316-326.

Mackensen, A., \& Douglas, R. G. (1989). Down-core distribution of live and dead deep-water benthic foraminifera in box cores from the Weddell Sea and the California continental borderland. Deep-Sea Research, 36(6), 879-900.

Margreth, S., Rüggeberg, A., \& Spezzaferri, S. (2009). Benthic foraminifera as bioindicator for cold-water coral reef ecosystems along the Irish margin. Deep Sea Research Part I: Oceanographic Research Papers, 56(12), 2216-2234.

Mienis, F., de Stigter, H. C., White, M., Duineveld, G., de Haas, H., \& van Weering, T. C. E. (2007). Hydrodynamic controls on coldwater coral growth and carbonate-mound development at the SW and SE Rockall Trough Margin, NE Atlantic Ocean. Deep Sea Research Part I: Oceanographic Research Papers, 54(9), $1655-1674$.

Mohn, C., Rengstorf, A., White, M., Duineveld, G., Mienis, F., Soetaert, K., et al. (2014). Linking benthic hydrodynamics and cold-water coral occurrences: A high-resolution model study at three cold-water coral provinces in the NE Atlantic. Progress in Oceanography, 122, 92-104.

Morigi, C., Sabbatini, A., Vitale, G., Pancotti, I., Gooday, A. J., Duineveld, G. C. A., et al. (2012). Foraminiferal biodiversity associated with cold-water coral carbonate mounds and open slope of SE Rockall Bank (Irish continental margin-NE Atlantic). Deep Sea Research Part I: Oceanographic Research Papers, 59, 54-71.

Murray, J. W. (2006). Ecology and applications of benthic foraminifera. Cambridge: Cambridge University Press.

Murray, J. W., \& Alve, E. (1993). The habitat of the foraminifer Paratrochammina (Lepidoparatrochammina) haynesi. Journal of Micropalaeontology, 12(1), 34. 
Rice, A. L., Billett, D. S. M., Thurston, M. H., \& Lampitt, R. S. (1991). The Institute of Oceanographic Sciences biology programme in the porcupine seabight: Background and general introduction. Journal of the Marine Biological Association of the United Kingdom, 71(02), 281.

Roberts, J. M., Wheeler, A. J., \& Freiwald, A. (2006). Reefs of the deep: The biology and geology of cold-water coral ecosystems. Science, 312, 543-547.

Rüggeberg, A., Dullo, C., Dorschel, B., \& Hebbeln, D. (2007). Environmental changes and growth history of a cold-water carbonate mound (Propeller Mound, Porcupine Seabight). International Journal of Earth Sciences, 96(1), 57-72.

Rüggeberg, A., Flögel, S., Dullo, W.-C., Hissmann, K., \& Freiwald, A. (2011). Water mass characteristics and sill dynamics in a subpolar cold-water coral reef setting at Stjernsund, northern Norway. Marine Geology, 282(1-2), 5-12.

Schmiedl, G., De Bovée, F., Buscail, R., Charriere, B., Hemleben, C., Medernach, L., et al. (2000). Trophic control of benthic foraminiferal abundance and microhabitat in the bathyal Gulf of Lions, western Mediterranean Sea. Marine Micropaleontology, 40(3), 167-188.

Schönfeld, J. (2002). Recent benthic foraminiferal assemblages in deep high-energy environments from the Gulf of Cadiz (Spain). Marine Micropaleontology, 44(3-4), 141-162.

Schönfeld, J., Alve, E., Geslin, E., Jorissen, F. J., Korsun, S., \& Spezzaferri, S. (2012). The FOBIMO (FOraminiferal BIoMOnitoring) initiative-towards a standardised protocol for soft-bottom benthic foraminiferal monitoring studies. Marine Micropaleontology, 94-95, 1-13.

Schönfeld, J., Dullo, W.-C., Pfannkuche, O., Freiwald, A., Rüggeberg, A., Schmidt, S., et al. (2011). Recent benthic foraminiferal assemblages from cold-water coral mounds in the Porcupine Seabight. Facies, 57(2), 187-213.

Smeulders, G. G. B., Koho, K. A., de Stigter, H. C., Mienis, F., de Haas, H., \& van Weering, T. C. E. (2014). Cold-water coral habitats of Rockall and Porcupine Bank, NE Atlantic Ocean: Sedimentary facies and benthic foraminiferal assemblages. Deep Sea Research Part II: Topical Studies in Oceanography, 99, 270-285.

Spezzaferri, S., Rüggeberg, A., Stalder, C., \& Margreth, S. (2013). Benthic foraminifer assemblages from Norwegian cold-water coral reefs. Journal of Foraminiferal Research, 43(1), 21-39.

Spezzaferri, S., Vertino, A., Addamo, A. M., Backers, J., Baratti, V., Constandache, M., Camozzi, O., El Kateb, A., Gennari, G., Leuzinger, L., McGrath, M., McHugh, S. K., Naudts, L., Savini, A., \& Stalder, C. (2012). Cruise report: Cold-water coral ecosystems from the Moira Mounds (NE Atlantic): Affinities and differences with modern and Pleistocene Mediterranean counterparts. EUROFLEETS cruise summary report (cruise no. 2012/16).

Stalder, C., Spezzaferri, S., Rüggeberg, A., Pirkenseer, C., \& Gennari, G. (2014). Late Weichselian deglaciation and early Holocene development of a cold-water coral reef along the Lopphavet shelf (Northern Norway) recorded by benthic foraminifera and ostracoda. Deep Sea Research Part II: Topical Studies in Oceanography, 99, 249-269.

Stalder, C., Vertino, A., Rosso, A., Rüggeberg, A., Pirkenseer, C., Spangenberg, J. E., et al. (2015). Microfossils, a key to unravel cold-water carbonate mound evolution through time: Evidence from the eastern Alboran Sea. PLoS One, 10(10), e0140223.

Stefanoudis, P. V., Bett, B. J., \& Gooday, A. J. (2016). Abyssal hills: Influence of topography on benthic foraminiferal assemblages. Progress in Oceanography, 148, 44-55.

Sun, X., Corliss, B. H., Brown, C. W., \& Showers, W. J. (2006). The effect of primary productivity and seasonality on the distribution of deep-sea benthic foraminifera in the North Atlantic. Deep Sea Research Part I: Oceanographic Research Papers, 53(1), 28-47.

Van Aken, H. M., \& Becker, G. (1996). Hydrography and throughflow in the north-eastern North Atlantic Ocean: The NANSEN project. Progress in Oceanography, 38, 297-346.

Van Oostende, N., Harlay, J., Vanelslander, B., Chou, L., Vyverman, W., \& Sabbe, K. (2012). Phytoplankton community dynamics during late spring coccolithophore blooms at the continental margin of the Celtic Sea (North East Atlantic, 2006-2008). Progress in Oceanography, 104, 1-16.

Van Rooij, D., Blamart, D., Richter, T., Wheeler, A., Kozachenko, M., \& Henriet, J.-P. (2007). Quaternary sediment dynamics in the Belgica mound province, Porcupine Seabight: Ice-rafting events and contour current processes. International Journal of Earth Sciences, 96(1), 121-140.

Vertino, A., Spezzaferri, S., Rüggeberg, A., Stalder, C., \& Wheeler, A. J. (2015). An overview on cold-water coral ecosystems and facies. In S. Spezzaferri, A. Rüggeberg, \& C. Stalder (Eds.), Atlas of benthic foraminifera from cold-water coral reefs (Vol. 44, pp. 12-19). Special Publication/Cushman Foundation for Foraminiferal Research.

Walton, W. R. (1952). Techniques for recognition of living foraminifera. Contributions from the Cushman Foundation for Foraminiferal Research, 3, 56-60.

Wehrmann, L. M., Knab, N. J., Pirlet, H., Unnithan, V., Wild, C., \& Ferdelman, T. G. (2009). Carbon mineralization and carbonate preservation in modern cold-water coral reef sediments on the Norwegian shelf. Biogeosciences, 6, 663-680.

Wheeler, A. J., \& Science Party. (2011). Cruise report CE11009: RV celtic explorer \& Holland 1 ROV. VENTuRE survey: VENTs and REefs deep-sea ecosystem study of the $45^{\circ}$ North MAR hydrothermal vent field and the cold-water coral Moira Mounds, Porcupine Seabight. Unpublished report. University College Cork, Ireland.

Wheeler, A. J., Beyer, A., Freiwald, A., de Haas, H., Huvenne, V. A. I., Kozachenko, M., et al. (2007). Morphology and environment of cold-water coral carbonate mounds on the NW European margin. International Journal of Earth Sciences, 96(1), 37-56.

Wheeler, A. J., Kozachenko, M., Beyer, A., Foubert, A., Huvenne, V. A. I., Klages, M., et al. (2005). Sedimentary processes and carbonate mounds in the Belgica Mound province, Porcupine Seabight, NE Atlantic. In A. Freiwald \& J. M. Roberts (Eds.), Cold-water corals and ecosystems (pp. 571-603). Berlin: Springer.

Wheeler, A. J., Kozachenko, M., Henry, L.-A., Foubert, A., de Haas, H., Huvenne, V. A. I., et al. (2011). The Moira Mounds, small cold-water coral banks in the Porcupine Seabight, NE Atlantic: Part A-an early stage growth phase for future coral carbonate mounds? Marine Geology, 282(1-2), 53-64.

White, M. (2007). Benthic dynamics at the carbonate mound regions of the Porcupine Sea Bight continental margin. International Journal of Earth Sciences, 96(1), 1-9.

Wienberg, C., Hebbeln, D., Fink, H. G., Mienis, F., Dorschel, B., Vertino, A., et al. (2009). Scleractinian cold-water corals in the Gulf of Cádiz-first clues about their spatial and temporal distribution. Deep Sea Research Part I, 56, 1873-1893.

Wild, C., Wehrmann, L. M., Mayr, C., Schöttner, S. I., Allers, E., \& Lundälv, T. (2009). Microbial degradation of cold-water coralderived organic matter: Potential implication for organic $\mathrm{C}$ cycling in the water column above Tisler Reef. Aquatic Biology, 7, 71-80.

Wollenburg, J. E., \& Mackensen, A. (2009). The ecology and distribution of benthic foraminifera at the Håkon Mosby mud volcano (SW Barents Sea slope). Deep Sea Research Part I: Oceanographic Research Papers, 56(8), 1336-1370. 